\title{
Association between Interleukin 35 Gene Single Nucleotide Polymorphisms and Systemic Lupus Erythematosus in a Chinese Han Population
}

\author{
Shi-Yang Guan ${ }^{1,2}$, , Li-Na Liu ${ }^{1,2}$, Yan-Mei Mao ${ }^{1,2}$, Chan-Na Zhao ${ }^{1,2}$, Qian $\mathrm{Wu}^{1,2}$, \\ Yi-Lin Dan ${ }^{1,2}$, Napoleon Bellua Sam ${ }^{1,2}$ and Hai-Feng Pan 1,2,*(D) \\ 1 Department of Epidemiology and Biostatistics, School of Public Health, Anhui Medical University, \\ 81 Meishan Road, Hefei 230032, China; gsy92@foxmail.com (S.-Y.G.); pachyrhizus123@sina.com (L.-N.L.); \\ mym199507@163.com (Y.-M.M.); zcn19940602@163.com (C.-N.Z.); qianwu1994@163.com (Q.W.); \\ danyilin98@163.com (Y.-L.D.); belluadsm@yahoo.com (N.B.S.) \\ 2 Anhui Province Key Laboratory of Major Autoimmune Diseases, Hefei 230032, China \\ * Correspondence: panhaifeng@ahmu.edu.cn; Tel.: +86-551-65161165; Fax: +86-551-65161171
}

Received: 1 March 2019; Accepted: 19 April 2019; Published: 22 April 2019

\begin{abstract}
Interleukin-35 (IL-35) exerts crucial roles in the pathogenesis and development of systemic lupus erythematosus (SLE), in this study we aim to explore the associations between IL-35 gene polymorphisms and the susceptibility, clinical features and plasma IL-35 levels of SLE patients, respectively. 490 SLE patients and 489 healthy controls were recruited in our study. The correlations between the polymorphisms of seven SNPs of IL-35 encoding gene and the susceptibility, main clinical manifestations of SLE were evaluated, respectively. Plasma IL-35 levels were assessed in 76 SLE patients, and the associations between plasma IL-35 levels and the polymorphisms of genotyped SNPs were explored. There were significant associations between the polymorphisms of rs 4740 and the occurrence of renal disorder, hematological disorder in SLE patients, respectively $(p=0.001 ; p=0.001)$. In addition, there were no significant associations observed between the genotype frequencies of genotyped SNPs and the risk of SLE, plasma IL-35 levels, respectively. The polymorphism of rs 4740 of IL-35 encoding gene is associated with the occurrence of renal disorder and hematological disorder of SLE patients.
\end{abstract}

Keywords: interleukin-35; systemic lupus erythematosus; gene single nucleotide polymorphisms; autoimmune diseases

\section{Introduction}

Systemic lupus erythematosus (SLE) is a prototypic autoimmune disease that is characterized by the impaired immune tolerance of the immune system and the massive production of autoantibody, and eventually leads to a variety of tissues' and organs' functions being damaged, such as skin, blood vessels, kidney, etc [1-4]. It is more prevalent in women than men, and its diverse manifestations and disease heterogeneity pose great challenges to the physical and mental health of women of childbearing age. $[2,5,6]$. Although significant advances have been made in the current studies of SLE, the etiology and pathogenesis of the disease remain unclear, and generally believe to be the result of the interaction of environmental, genetic and immune factors [7-11].

Currently, the imbalance between Treg cells and Th17 cells is considered to be an essential immunopathogenesis of multiple autoimmune diseases [12-18]. Interleukin 35 (IL-35), the latest identified cytokine of interleukins 12 (IL-12) family, is consisted of two subunits (p35 and EBI3) [19-21] and secreted by Treg cells [22,23] and activated B cells [21,24], etc. Studies revealed that IL-35 facilitates the differentiation and optimal immunosuppression of Treg cells [22,23], and restrains the propagation 
and function of Th17 cells [25-27]; the levels of IL-35 and IL-35 mRNA are significantly elevated in SLE patients [28], and IL-35 can significantly relieve lupus flare and lupus nephritis, and reduce the plasma levels of proinflammatory cytokines (IFN- $\gamma$, TNF- $\alpha$, IL-6 and IL-17A) and elevate the plasma levels of anti-inflammatory cytokines (IL-10 and IL-2) in MRL(Murphy Roths Large)/LPR mice [28]. These findings suggest that IL-35 exerts crucial roles in the pathogenesis and development of SLE.

The encoding gene of p35 subunit, $I L-12 A$, is located on chromosome 3q25.33, and several $I L-12 A$ polymorphisms were associated with the susceptibilities to primary biliary cirrhosis (PBC), Graves' disease and Alzheimer's disease [29-31]; EBI3, the encoding gene of another subunit, EBI3, is located on chromosome 19q13.3, and the polymorphisms of EBI3 rs428253, rs4740 and rs4905 were associated with the decreased risk of developing ulcerative colitis (UC) [32]. Considering there is no evidence about the effects of IL-35 gene polymorphisms on SLE, in this case-control study we explored the associations between IL-35 gene polymorphisms and the susceptibility, main clinical manifestations, plasma IL-35 levels of SLE patients in a Chinese Han population, respectively.

\section{Materials and Methods}

\subsection{Subjects}

All the participants included in our study were of Chinese Han ancestry. A total of 490 SLE patients were recruited in our study from Department of Rheumatism and Immunity, the First Affiliated Hospital of Anhui Medical University and Department of Rheumatology and Immunology, Anhui Provincial Hospital, all the SLE patients met the criteria for the classification of SLE (American College of Rheumatology, 1997), and renal disorder of SLE was defined if any one of following definitions was satisfied: (a) Persistent proteinuria $>0.5 \mathrm{~g} / \mathrm{d}$ or $>3+$ if quantitation not performed; (b) Cellular casts: may be red blood cell, hemoglobin, granular, tubular, or mixed [33]. 489 healthy controls were selected from the Health Examination Center, the First Affiliated Hospital of Anhui Medical University, all the healthy controls eligible to the inclusion criteria (a. do not meet any of the criteria for SLE classification, b. self and immediate relatives have no previous history of autoimmune diseases, c. match with SLE patients by age and gender). The informed consent was obtained from all the participants, and demographic profiles and clinical characteristics were collected from the participants. This study was approved by the Medical Ethics Committee of Anhui Medical University.

\subsection{SNP Selection, Genotyping and Enzyme-Linked Immunosorbent Assay (ELISA)}

The single nucleotide polymorphisms (SNPs) of IL-35 encoding gene, IL-12A and EBI3, were selected from HapMap database of Han Chinese population (CHB) in Beijing (HapMap Data Rel 24/phaseII Nov08, on NCBI B36 assembly, dbSNP b126) with minor allele frequency (MAF) $\geq 0.05$. The pair-wise linkage disequilibrium (LD) between SNPs with $\mathrm{r}^{2}$ threshold of 0.8 was calculated by Haploview software (http://www.broad.mit.edu/haploview/haploview) [34]. Eventually, seven tag SNPs were included in our study, including rs2227314, rs2243115, rs2243123, rs2243131 in IL-12A gene, and s428253, rs4740, rs9807813 in EBI3 gene, the observed genotype frequencies of all genotyped SNPs were consistent with that of expected ones in healthy controls (all $p>0.05$ ) (Table 1), and further genotyped by high-throughput SNPscan ${ }^{\mathrm{TM}}$ genotyping assays (Genesky Biotechnologies Inc., Shanghai, China). Plasma IL-35 levels were assessed by Human IL-35 ELISA kits according to the manufacturer's instruction (R \& D Systems, Inc. Minneapolis, MN, USA). 
Table 1. SNPs genotyped in $I L-12 A$ and EBI3 genes.

\begin{tabular}{cccccccc}
\hline Gene & SNP ID & Chr & $\begin{array}{c}\text { Chr } \\
\text { Position }\end{array}$ & Allele & mRNA & Region & $\begin{array}{c}p \text { Value for } \\
\text { HWE Test }\end{array}$ \\
\hline$I L-12 A$ & rs2227314 & 3 & 159712054 & G/T & NM_000882.3 & Intron 6 & 0.902 \\
$I L-12 A$ & rs2243115 & 3 & 159706280 & G/T & NM_000882.3 & 5' Flanking & 0.908 \\
$I L-12 A$ & rs2243123 & 3 & 159709651 & C/T & NM_000882.3 & Intron 2 & 0.891 \\
$I L-12 A$ & rs2243131 & 3 & 159712058 & A/C & NM_000882.3 & Intron 6 & 0.954 \\
$E B I 3$ & rs428253 & 19 & 4229913 & C/G & NM_005755.2 & Intron 1 & 0.262 \\
$E B I 3$ & rs4740 & 19 & 4236996 & A/G & NM_005755.2 & Exon 5 & 0.887 \\
$E B I 3$ & rs9807813 & 19 & 4232415 & C/T & NM_005755.2 & Intron 2 & 0.322 \\
\hline
\end{tabular}

\subsection{Statistical Analysis}

Statistical analysis was performed by the Statistical Package for the Social Science (SPSS) version 23.0 for Windows. Shapiro-Wilk test was implemented for testing the normality of data, continuous data was described as mean $\pm \mathrm{SD}$ for normally distributed data or median (interquartile range, IQR) for non-normally distributed data, and categorical data was presented as frequencies and percentages. The difference of continuous data was evaluated by $t$-test, F-test or Mann-Whitney $U$ test, and that of categorical data was fulfilled by chi-square test or Fisher exact test. Hardy-Weinberg equilibrium (HWE) was tested to compare the frequencies of observed genotype to that of expected ones [35], and haplotype analyses were completed using online platform SHEsis (http://analysis.bio-x.cn/myAnalysis.php) [36]. A two-sided $p$ value less than 0.05 was considered as statistically significant.

\section{Results}

\subsection{Demographic Characteristics, Clinical Features of Subjects}

The demographic characteristics of all participants are presented in Table 2, there were no significant differences in age and gender between SLE patients and healthy controls, respectively $\left(t=1.324, p=0.186 ; \chi^{2}=0.096, p=0.757\right)$. The clinical characteristics of SLE patients are illustrated in Table 2, the major clinical features of SLE patients were butterfly rash $(45.5 \%)$, arthritis $(49.2 \%)$, hematological disorder (68.0\%) and immunological disorder (73.3\%).

Table 2. Demographic characteristics and clinical features of participants.

\begin{tabular}{ccccc}
\hline Variable & $\begin{array}{c}\text { SLE Patients } \\
(\mathbf{n}=\mathbf{4 9 0 )}\end{array}$ & $\begin{array}{c}\text { Healthy Controls } \\
(\mathbf{n}=\mathbf{4 8 9 )}\end{array}$ & $\boldsymbol{t} / \boldsymbol{\chi}^{2}$ & $\boldsymbol{p}$ Value \\
\hline Age (years) & $37.57 \pm 11.49$ & $38.53 \pm 11.31$ & $1.324^{*}$ & 0.186 \\
Gender, $\mathrm{n}(\%)$ & $56(11.4)$ & $59(12.1)$ & $0.096^{* *}$ & 0.757 \\
Male & $434(88.6)$ & $430(88.0)$ & & \\
Female & $4.06(1.05-8.90) * * *$ & & \\
Disease duration, years & $223(45.5)$ & & \\
Butterfly rash, $\mathrm{n}(\%)$ & $93(19.0)$ & & \\
Discoid rash, $\mathrm{n}(\%)$ & $190(38.8)$ & & \\
Photosensitivity, $\mathrm{n}(\%)$ & $118(24.1)$ & & \\
Oral ulcers, $\mathrm{n}(\%)$ & $241(49.2)$ & & \\
Arthritis, $\mathrm{n}(\%)$ & $45(9.2)$ & & \\
Pleurisy, $\mathrm{n}(\%)$ & $184(37.6)$ & & \\
Renal disorder, $\mathrm{n}(\%)$ & $21(4.3)$ & & \\
Neurological disorder, $\mathrm{n}(\%)$ & $333(68.0)$ & & \\
Hematological disorder, $\mathrm{n}(\%)$ & $359(73.3)$ & & \\
Immunological disorder, $\mathrm{n}(\%)$ & $* t$-test; ${ }^{* *} \chi^{2}$ test; ${ }^{* * *}$ median (interquartile range).
\end{tabular}




\subsection{Association of IL-35 Gene Polymorphisms with Risk of SLE}

The allele frequencies and genotype frequencies of seven genotyped SNPs in SLE patients and healthy controls were presented in Table 3, there were no significant differences in allele frequencies and genotype frequencies between SLE patients and healthy controls in all seven genotyped SNPs (rs2227314, rs2243115, rs2243123, rs2243131, rs428253, rs4740 and 9807813, all $p>0.05$ ). Furthermore, we explored the IL-35 gene polymorphisms with risk of SLE under dominant, recessive and additive model, and there were also no significant differences in IL-35 gene polymorphisms between SLE patients and healthy controls in all seven genotyped SNPs (all $p>0.05$ ) (Table 3 ).

Table 3. Genotype and allele frequencies of genotyped SNPs in SLE patients and healthy controls.

\begin{tabular}{|c|c|c|c|c|c|c|c|c|}
\hline \multirow{2}{*}{ SNPs ID } & \multirow[t]{2}{*}{ Variable } & \multirow[t]{2}{*}{ Genotypes } & \multirow{2}{*}{$\begin{array}{c}\text { SLE } \\
\mathbf{n}\end{array}$} & \multirow{2}{*}{$\begin{array}{c}\text { Control } \\
\mathbf{n}\end{array}$} & \multirow{2}{*}{$x^{2}$} & \multirow[t]{2}{*}{$p$ Value } & \multirow{2}{*}{ OR } & \multirow{2}{*}{$95 \% C I$} \\
\hline & & & & & & & & \\
\hline \multirow[t]{11}{*}{ rs2227314 } & Genotypes & GG & 266 & 264 & 0.020 & 0.990 & & \\
\hline & & TG & 187 & 187 & & & & \\
\hline & & TT & 37 & 38 & & & & \\
\hline & Allele & G & 719 & 715 & 0.017 & 0.897 & 1.013 & $0.830-1.238$ \\
\hline & & $\mathrm{T}$ & 261 & 263 & & & & \\
\hline & Dominant model & GG & 266 & 264 & 0.009 & 0.925 & 1.012 & $0.787-1.301$ \\
\hline & & $\mathrm{TT}+\mathrm{TG}$ & 224 & 225 & & & & \\
\hline & Recessive model & GG + TG & 453 & 451 & 0.017 & 0.897 & 1.032 & $0.644-1.652$ \\
\hline & & TT & 37 & 38 & & & & \\
\hline & Additive model & GG & 266 & 264 & 0.019 & 0.890 & 1.035 & $0.638-1.678$ \\
\hline & & TT & 37 & 38 & & & & \\
\hline \multirow[t]{11}{*}{ rs2243115 } & Genotypes & TT & 445 & 444 & & $1.000 *$ & & \\
\hline & & TG & 44 & 45 & & & & \\
\hline & & GG & 1 & 0 & & & & \\
\hline & Allele & $\mathrm{T}$ & 934 & 933 & 0.009 & 0.922 & 0.979 & $0.643-1.492$ \\
\hline & & G & 46 & 45 & & & & \\
\hline & Dominant model & TT & 445 & 444 & 0.000 & 0.992 & 1.002 & $0.650-1.546$ \\
\hline & & GG + TG & 45 & 45 & & & & \\
\hline & Recessive model & $\mathrm{TT}+\mathrm{TG}$ & 489 & 489 & 0.000 & $1.000^{* *}$ & & \\
\hline & & GG & 1 & 0 & & & & \\
\hline & Additive model & TT & 445 & 444 & 0.000 & 1.000 ** & & \\
\hline & & GG & 1 & 0 & & & & \\
\hline \multirow[t]{11}{*}{ rs2243123 } & Genotypes & TT & 422 & 416 & & 0.250 ** & & \\
\hline & & $\mathrm{TC}$ & 62 & 71 & & & & \\
\hline & & $\mathrm{CC}$ & 6 & 2 & & & & \\
\hline & Allele & $\mathrm{T}$ & 906 & 903 & 0.010 & 0.922 & 1.017 & $0.728-1.420$ \\
\hline & & $\mathrm{C}$ & 74 & 75 & & & & \\
\hline & Dominant model & $\mathrm{TT}$ & 422 & 416 & 0.219 & 0.640 & 1.089 & $0.762-1.556$ \\
\hline & & $\mathrm{CC}+\mathrm{TC}$ & 68 & 73 & & & & \\
\hline & Recessive model & $\mathrm{TT}+\mathrm{TC}$ & 484 & 487 & 1.128 & $0.288^{* *}$ & 0.331 & $0.067-1.649$ \\
\hline & & $\mathrm{CC}$ & 6 & 2 & & & & \\
\hline & Additive model & TT & 422 & 416 & 1.065 & $0.302 * *$ & 0.338 & $0.068-1.685$ \\
\hline & & $\mathrm{CC}$ & 6 & 2 & & & & \\
\hline \multirow[t]{11}{*}{ rs2243131 } & Genotypes & AA & 385 & 370 & 1.218 & 0.544 & & \\
\hline & & $\mathrm{AC}$ & 97 & 109 & & & & \\
\hline & & $\mathrm{CC}$ & 8 & 10 & & & & \\
\hline & Allele & A & 867 & 849 & 1.245 & 0.265 & 1.166 & $0.890-1.527$ \\
\hline & & $\mathrm{C}$ & 113 & 129 & & & & \\
\hline & Dominant model & AA & 385 & 370 & 1.172 & 0.279 & 1.179 & $0.875-1.590$ \\
\hline & & $\mathrm{CC}+\mathrm{AC}$ & 105 & 119 & & & & \\
\hline & Recessive model & $\mathrm{AA}+\mathrm{AC}$ & 482 & 479 & 0.231 & 0.631 & 1.258 & $0.492-3.214$ \\
\hline & & $\mathrm{CC}$ & 8 & 10 & & & & \\
\hline & Additive model & AA & 385 & 370 & 0.302 & 0.583 & 1.301 & $0.508-3.332$ \\
\hline & & $\mathrm{CC}$ & 8 & 10 & & & & \\
\hline
\end{tabular}


Table 3. Cont

\begin{tabular}{|c|c|c|c|c|c|c|c|c|}
\hline \multirow[t]{2}{*}{ SNPs ID } & \multirow[t]{2}{*}{ Variable } & \multirow[t]{2}{*}{ Genotypes } & SLE & Control & \multirow[t]{2}{*}{$\chi^{2}$} & \multirow[t]{2}{*}{$p$ Value } & \multirow[t]{2}{*}{ OR } & \multirow[t]{2}{*}{$95 \% C I$} \\
\hline & & & $\mathbf{n}$ & $\mathbf{n}$ & & & & \\
\hline \multirow[t]{11}{*}{ rs 428253} & Genotypes & GG & 321 & 321 & 0.755 & 0.686 & & \\
\hline & & GC & 156 & 159 & & & & \\
\hline & & $\mathrm{CC}$ & 13 & 9 & & & & \\
\hline & Allele & G & 798 & 801 & 0.073 & 0.787 & 0.969 & $0.771-1.218$ \\
\hline & & $\mathrm{C}$ & 182 & 177 & & & & \\
\hline & Dominant model & GG & 321 & 321 & 0.002 & 0.965 & 0.994 & $0.764-1.294$ \\
\hline & & $\mathrm{CC}+\mathrm{GC}$ & 169 & 168 & & & & \\
\hline & Recessive model & GG + GC & 477 & 480 & 0.736 & 0.391 & 0.688 & $0.291-1.625$ \\
\hline & & $\mathrm{CC}$ & 13 & 9 & & & & \\
\hline & Additive model & GG & 321 & 321 & 0.703 & 0.402 & 0.692 & $0.292-1.642$ \\
\hline & & $\mathrm{CC}$ & 13 & 9 & & & & \\
\hline \multirow{11}{*}{ rs4740 } & Genotypes & GG & 172 & 161 & 0.545 & 0.762 & & \\
\hline & & GA & 224 & 233 & & & & \\
\hline & & AA & 94 & 95 & & & & \\
\hline & Allele & G & 568 & 555 & 0.293 & 0.588 & 1.051 & $0.878-1.257$ \\
\hline & & A & 412 & 423 & & & & \\
\hline & Dominant model & GG & 172 & 161 & 0.517 & 0.472 & 1.102 & $0.846-1.436$ \\
\hline & & $\mathrm{AA}+\mathrm{GA}$ & 318 & 328 & & & & \\
\hline & Recessive model & GG + GA & 396 & 394 & 0.009 & 0.923 & 1.016 & $0.740-1.395$ \\
\hline & & AA & 94 & 95 & & & & \\
\hline & Additive model & GG & 172 & 161 & 0.177 & 0.674 & 1.080 & $0.755-1.543$ \\
\hline & & AA & 94 & 95 & & & & \\
\hline \multirow[t]{11}{*}{ rs 9807813} & Genotypes & $\mathrm{CC}$ & 321 & 308 & 4.740 & 0.093 & & \\
\hline & & $\mathrm{TC}$ & 147 & 169 & & & & \\
\hline & & TT & 22 & 12 & & & & \\
\hline & Allele & $\mathrm{C}$ & 789 & 785 & 0.019 & 0.892 & 1.016 & $0.813-1.269$ \\
\hline & & $\mathrm{T}$ & 191 & 193 & & & & \\
\hline & Dominant model & $\mathrm{CC}$ & 321 & 308 & 0.679 & 0.410 & 1.116 & $0.859-1.450$ \\
\hline & & $\mathrm{TT}+\mathrm{TC}$ & 169 & 181 & & & & \\
\hline & Recessive model & $\mathrm{CC}+\mathrm{TC}$ & 468 & 477 & 3.026 & 0.082 & 0.535 & $0.262-1.094$ \\
\hline & & TT & 22 & 12 & & & & \\
\hline & Additive model & $\mathrm{CC}$ & 321 & 308 & 2.415 & 0.120 & 0.568 & $0.277-1.169$ \\
\hline & & TT & 22 & 12 & & & & \\
\hline
\end{tabular}

* Fisher's Exact Test; ${ }^{* *}$ Continuity Correction; OR, odds ratio; CI, confidence interval.

\subsection{Association of IL-35 Gene Polymorphisms with the Clinical Features of SLE Patients}

The associations between allele frequencies and genotype frequencies of seven genotyped SNPs and main clinical features of SLE patients were detailed in Supplementary Tables (Tables S1 to S7). There were significant differences in both genotype frequency and allele frequency of rs4740 between SLE patients with renal disorder and those without $\left(\chi^{2}=13.759, p=0.001 ; \chi^{2}=11.804, p=0.001\right)$; and there was a significant difference in genotype frequency of rs4740 between SLE patients with hematological disorder and those without $\left(\chi^{2}=6.683, p=0.036\right)$. However, there were no significant associations between genotype frequencies and allele frequencies of the other six SNPs (rs2227314, rs2243115, rs2243123, rs2243131, rs428253 and rs9807813) and the clinical features of SLE patients.

\subsection{Association of Plasma IL-35 Levels with IL-35 Genotypes in SLE Patients}

We randomly selected 76 plasma samples from 490 SLE patients and assessed their plasma IL-35 levels, the results revealed that there are no significant differences of plasma IL-35 levels in different IL-35 genotypes of each SNP, respectively (Table 4). 
Table 4. Associations of plasma IL-35 levels with IL-35 genotypes in SLE patients.

\begin{tabular}{|c|c|c|c|c|c|c|}
\hline \multirow{2}{*}{ SNP ID } & \multirow{2}{*}{ Genotypes } & \multirow{2}{*}{$n$} & \multicolumn{3}{|c|}{ IL-35 Level (pg/mL) } & \multirow{2}{*}{$p$ Value } \\
\hline & & & $M$ & $P 25$ & P75 & \\
\hline \multirow[t]{3}{*}{ rs2227314 } & GG & 46 & 61.51 & 55.7 & 72.96 & 0.538 \\
\hline & TG & 25 & 59.51 & 52.99 & 68.57 & \\
\hline & $\mathrm{TT}$ & 5 & 64.58 & 55.4 & 68.24 & \\
\hline \multirow[t]{2}{*}{ rs2243115 } & $\mathrm{TT}$ & 73 & 61.66 & 55.07 & 71.55 & 0.416 \\
\hline & TG & 3 & 59.51 & 56.11 & 59.79 & \\
\hline \multirow[t]{3}{*}{ rs2243123 } & $\mathrm{TT}$ & 70 & 54.23 & 60.05 & 71.51 & 0.315 \\
\hline & $\mathrm{TC}$ & 5 & 63.12 & 68.98 & 83.05 & \\
\hline & $\mathrm{CC}$ & 1 & 61.61 & - & - & \\
\hline \multirow[t]{3}{*}{ rs2243131 } & AA & 65 & 61.61 & 55.07 & 72.08 & 0.409 \\
\hline & $\mathrm{AC}$ & 10 & 57.88 & 48.19 & 66.74 & \\
\hline & $\mathrm{CC}$ & 1 & 67.51 & - & - & \\
\hline \multirow[t]{3}{*}{ rs428253 } & GG & 45 & 62.92 & 55.09 & 72.08 & 0.746 \\
\hline & GC & 30 & 59.23 & 54.14 & 70.32 & \\
\hline & $\mathrm{CC}$ & 1 & 63.72 & - & - & \\
\hline \multirow[t]{3}{*}{ rs 4740} & GG & 29 & 60.88 & 54.12 & 70.70 & 0.816 \\
\hline & GA & 29 & 58.71 & 53.7 & 72.98 & \\
\hline & AA & 18 & 63.52 & 57.87 & 72.62 & \\
\hline \multirow[t]{3}{*}{ rs9807813 } & $\mathrm{CC}$ & 51 & 61.61 & 54.99 & 71.46 & 0.666 \\
\hline & $\mathrm{TC}$ & 21 & 59.51 & 54.36 & 70.78 & \\
\hline & $\mathrm{TT}$ & 4 & 69.33 & 44.32 & 212.58 & \\
\hline
\end{tabular}

$M$, median; $P 25$, percentile 25 th, $P 75$, percentile 75 th, representing the interquartile range.

\subsection{Haplotype Analyses}

Five main haplotypes (GGTA, GTTA, TTCA, TTTA and TTC) were constructed for rs2227314, rs2243115, rs2243123 and rs2243131 in IL-12A locus, and five main haplotypes (CAC, CGC, GAC, GAT and GGC) were constructed for rs428253, rs4740 and rs9807813 in EBI3 locus. There were no significant differences in the frequency of each constructed haplotype in SLE patients and healthy controls (Tables 5 and 6).

Table 5. Haplotype analysis results among four SNPs in $I L-12 A$ locus.

\begin{tabular}{|c|c|c|c|c|c|c|c|c|}
\hline \multirow{2}{*}{ Haplotypes } & \multicolumn{2}{|c|}{ SLE } & \multicolumn{2}{|c|}{ Control } & \multirow{2}{*}{$x^{2}$} & \multirow{2}{*}{$\begin{array}{c}p \\
\text { Value }\end{array}$} & \multirow{2}{*}{ OR } & \multirow{2}{*}{$95 \% C I$} \\
\hline & n & $\%$ & n & $\%$ & & & & \\
\hline GGTA & 32.34 & $3.3 \%$ & 28.92 & $3.0 \%$ & 0.188 & 0.665 & 1.119 & $0.672-1.864$ \\
\hline GTTA & 681.72 & $69.6 \%$ & 686.08 & $70.2 \%$ & 0.095 & 0.758 & 0.969 & $0.795-1.182$ \\
\hline TTCA & 63.76 & $6.5 \%$ & 62.4 & $6.4 \%$ & 0.012 & 0.912 & 1.021 & $0.711-1.465$ \\
\hline TTTA & 80.07 & $8.2 \%$ & 67.12 & $6.9 \%$ & 1.200 & 0.273 & 1.207 & $0.861-1.692$ \\
\hline TTTC & 99.68 & $10.2 \%$ & 110.64 & $11.3 \%$ & 0.672 & 0.412 & 0.887 & $0.666-1.182$ \\
\hline
\end{tabular}

Total $\chi^{2}=1.927, d f=4, P=0.749$. All the haplotypes with a frequency $<0.03$ were ignored in the analysis. OR, odds ratio; $\mathrm{CI}$, confidence interval. 
Table 6. Haplotype analysis results among three SNPs in EBI3 locus.

\begin{tabular}{|c|c|c|c|c|c|c|c|c|}
\hline \multirow{2}{*}{ Haplotypes } & \multicolumn{2}{|c|}{ SLE } & \multicolumn{2}{|c|}{ Control } & \multirow{2}{*}{$x^{2}$} & \multirow{2}{*}{$p$ Value } & \multirow{2}{*}{$O R$} & \multirow{2}{*}{$95 \% C I$} \\
\hline & $\mathbf{n}$ & $\%$ & n & $\%$ & & & & \\
\hline CAC & 119.38 & $12.2 \%$ & 103.00 & $10.5 \%$ & 1.433 & 0.231 & 1.186 & $0.897-1.570$ \\
\hline CGC & 57.14 & $5.8 \%$ & 71.86 & $7.3 \%$ & 1.744 & 0.187 & 0.785 & $0.548-1.125$ \\
\hline GAC & 109.22 & $11.1 \%$ & 132.13 & $13.5 \%$ & 2.388 & 0.122 & 0.808 & $0.616-1.059$ \\
\hline GAT & 178.17 & $18.2 \%$ & 185.74 & $19.0 \%$ & 0.161 & 0.688 & 0.954 & 0.760-1.199 \\
\hline GGC & 503.26 & $51.4 \%$ & 478.01 & $48.9 \%$ & 1.511 & 0.219 & 1.118 & $0.936-1.336$ \\
\hline
\end{tabular}

Total $\chi^{2}=5.863, d f=4, p=0.230$. All the haplotypes with a frequency $<0.03$ were ignored in the analysis. OR, odds ratio; $\mathrm{CI}$, confidence interval.

\section{Discussion}

The disturbances in balance between Treg cells and Th17 cells have been considered as a new paradigm for pathogenesis of autoimmune diseases $[3,18,37]$. IL-35 as a newly identified cytokine of IL-12 family exerts an indispensable role in the balance of Treg cells and Th17 cells $[4,38]$. IL-35 abnormally elevated in SLE patients [39], and significantly alleviated lupus flare, lupus nephritis and plasma levels of proinflammatory cytokines in MRL/lpr mice [28]; there was an inverse correlation between serum IL-35 levels and disease activity in rheumatoid arthritis (RA) patients [40], and IL-35 significantly relieved the synovial hypertrophy and bone destruction of RA model [41]; serum IL-35 were significantly over-expressed in systemic sclerosis (SSc) patients [42], and the frequency of Treg cells, the major source of IL-35, was associated with clinical phenotype and progression of SSc patients [43]; IL-35 levels significantly reduced in inflammatory bowel diseases (IBD) patients and idiopathic thrombocytopenic purpura (ITP) patients [44,45], exhibited a negative association with disease activity of IBD patients and a positive association with platelet counts in active ITP patients $[44,45]$. All of this evidence implies that IL-35 is involved in the pathogenesis and progression of autoimmune diseases.

Several studies have explored the relations between the gene single nucleotide polymorphisms of interleukin 35 encoding genes (IL-12A and EBI3) and susceptibility to autoimmune diseases: genome-wide association analysis revealed that genetic variants of rs6441286, rs574808 in IL-12A locus were significantly associated with the PBC in North American white subjects [29]; Guo et al. [30] reported that the high frequency of allele A of $I L-12 A$ rs 568408 related to the high Graves' disease risk in two Chinese cohort ; IL-12A rs568408 was significantly associated with the risk of late-onset Alzheimer's disease (LOAD), IL-12A rs2243115 elevated LOAD risk only in Apolipoprotein E, type $€ 4$ allele carriers and genotype frequencies of $I L-12 A$ rs 568408 had no significant associations with the risk of RA in Han Chinese populations [31,46]; there were significant relations between EBI3 rs428253 and protective effects against allergic rhinitis in Chinese subjects [47]; rs428253, rs4740 and rs4905 in EBI3 locus significantly correlated with the decreased UC risk in the Mexican population [32].

In this study, we explored the associations between IL-35 gene single nucleotide polymorphisms with genetic susceptibility to SLE in a Chinese Han population. There were significant associations observed between the polymorphisms of rs 4740 and the occurrence of renal disorder and hematological disorder in SLE patients, respectively, which echoed previous studies that rs4740 polymorphism exhibits protective effects on UC and pulmonary tuberculosis in Mexican and Chinese populations, respectively $[32,48]$. Lupus nephritis, as one of the most devastating complications of SLE, predicts poor long-term outcomes with more than four-fold increase in mortality [49]. In US, at the time of diagnosis around 35\% SLE patients have clinical evidence of nephritis, within a decade of the illness estimated total of 50-60\% patients develop nephritis [50]. In the present study, the prevalence of renal disorder in SLE patients was $37.6 \%$ with median disease duration of 4.06 years. Previous study has suggested that serum IL-35 could be served as a potential biomarker of renal involvement in SLE patients; the serum levels of IL-35 were significantly lower in nephritis patients with higher levels of serum creatinine, blood urea nitrogen and blood uric acid [51]. Our result adds novel evidence in 
elucidating the genetic underpinnings driving nephritis among SLE patients. However, there were no significant differences in both genotype frequencies and allele frequencies of all seven genotyped SNPs (rs2227314, rs2243115, rs2243123, rs2243131, rs428253, rs4740 and rs9807813) between SLE patients and healthy controls, and no significant associations between the polymorphisms of other genotyped SNPs (rs2227314, rs2243115, rs2243123, rs2243131, rs428253 and rs9807813) and the occurrence of main clinical manifestations in SLE patients. Posadas-Sánchez et al. [52] illustrated that in healthy controls, IL-35 serum levels are significant different among different genotypes of rs4740 and rs4905, respectively. In this study, ELISA results demonstrated that plasma IL-35 levels have no significant association with genotype polymorphisms of all genotyped SNPs.

As far as we know, this is the first study explored about the associations between IL-35 gene single nucleotide polymorphisms and the genetic susceptibility to autoimmune diseases, in which IL-35 encoding genes, IL-12A and EBI3, were analyzed together. However, one limitation of our study should be considered, i.e., there was no information about the medication taking history of SLE patients and some of the SLE patients may have been treated with steroids or immunosuppressive agents, which potentially concealed the actual associations between plasma IL-35 levels and IL-35 gene single nucleotide polymorphisms, so further studies with known medication history of participants are needed to verify the results.

\section{Conclusions}

In conclusion, there is a significant association between the polymorphism of rs4740 and the occurrence of certain clinical manifestations in SLE patients, providing new clues for the prevention, diagnosis and treatment of SLE.

Supplementary Materials: The following are available online at http://www.mdpi.com/2218-273X/9/4/157/s1, Supplementary Tables S1-S7.

Author Contributions: Conceptualization, H.-F.P.; methodology, H.-F.P. and S.-Y.G.; software, S.-Y.G., L.-N.L., Y.-M.M., C.-N.Z., Q.W. and Y.-L.D.; validation, H.-F.P.; formal analysis, S.-Y.G.; investigation, S.-Y.G., L.-N.L., Y.-M.M., C.-N.Z., Q.W. and Y.-L.D.; resources, H.-F.P.; data curation, S.-Y.G.; writing-original draft preparation, S.-Y.G. and N.B.S.; writing-review and editing, H.-F.P. and S.-Y.G.; supervision, H.-F.P. and S.-Y.G.; project administration, H.-F.P.; funding acquisition, H.-F.P.

Funding: This work was funded by the National Natural Science Foundation of China (81573222).

Conflicts of Interest: The authors declare no conflict of interest.

\section{References}

1. Tsokos, G.C. Systemic lupus erythematosus. N. Engl. J. Med. 2011, 365, 2110-2121. [CrossRef]

2. D'Cruz, D.P.; Khamashta, M.A.; Hughes, G.R. Systemic lupus erythematosus. Lancet 2007, 369, 587-596. [CrossRef]

3. Guan, S.Y.; Leng, R.X.; Tao, J.H.; Li, X.P.; Ye, D.Q.; Olsen, N.; Zheng, S.G.; Pan, H.F. Hypoxia-inducible factor-1alpha: A promising therapeutic target for autoimmune diseases. Expert Opin. Ther. Targets 2017, 21, 715-723. [CrossRef]

4. Guan, S.Y.; Leng, R.X.; Khan, M.I.; Qureshi, H.; Li, X.P.; Ye, D.Q.; Pan, H.F. Interleukin-35: A Potential Therapeutic Agent for Autoimmune Diseases. Inflammation 2017, 40, 303-310. [CrossRef] [PubMed]

5. Meyer, O. Making pregnancy safer for patients with lupus. Joint Bone Spine 2004, 71, 178-182. [CrossRef]

6. Smith, P.P.; Gordon, C. Systemic lupus erythematosus: Clinical presentations. Autoimmun. Rev. 2010, 10, 43-45. [CrossRef] [PubMed]

7. Gulati, G.; Brunner, H.I. Environmental triggers in systemic lupus erythematosus. Semin Arthritis Rheum 2017, 47, 710-717. [CrossRef] [PubMed]

8. Moulton, V.R.; Suarez-Fueyo, A.; Meidan, E.; Li, H.; Mizui, M.; Tsokos, G.C. Pathogenesis of Human Systemic Lupus Erythematosus: A Cellular Perspective. Trends Mol. Med. 2017, 23, 615-635. [CrossRef]

9. Wang, H.; Wang, J.; Xia, Y. Defective Suppressor of Cytokine Signaling 1 Signaling Contributes to the Pathogenesis of Systemic Lupus Erythematosus. Front. Immunol. 2017, 8, 1292. [CrossRef] 
10. Morel, L. Immunometabolism in systemic lupus erythematosus. Nat. Rev. Rheumatol. 2017, 13, $280-290$. [CrossRef]

11. Koutsokeras, T.; Healy, T. Systemic lupus erythematosus and lupus nephritis. Nat. Rev. Drug Discov. 2014, 13, 173-174. [CrossRef]

12. Talaat, R.M.; Mohamed, S.F.; Bassyouni, I.H.; Raouf, A.A. Th1/Th2/Th17/Treg cytokine imbalance in systemic lupus erythematosus (SLE) patients: Correlation with disease activity. Cytokine 2015, 72, 146-153. [CrossRef] [PubMed]

13. Zhu, M.; Mo, H.; Li, D.; Luo, X.; Zhang, L. Th17/Treg imbalance induced by increased incidence of atherosclerosis in patients with systemic lupus erythematosus (SLE). Clin. Rheumatol. 2013, 32, 1045-1052. [CrossRef] [PubMed]

14. Niu, Q.; Cai, B.; Huang, Z.C.; Shi, Y.Y.; Wang, L.L. Disturbed Th17/Treg balance in patients with rheumatoid arthritis. Rheumatol. Int. 2012, 32, 2731-2736. [CrossRef] [PubMed]

15. Wang, W.; Shao, S.; Jiao, Z.; Guo, M.; Xu, H.; Wang, S. The Th17/Treg imbalance and cytokine environment in peripheral blood of patients with rheumatoid arthritis. Rheumatol. Int. 2012, 32, 887-893. [CrossRef] [PubMed]

16. Baraut, J.; Michel, L.; Verrecchia, F.; Farge, D. Relationship between cytokine profiles and clinical outcomes in patients with systemic sclerosis. Autoimmun. Rev. 2010, 10, 65-73. [CrossRef] [PubMed]

17. Barbi, J.; Pardoll, D.; Pan, F. Metabolic control of the Treg/Th17 axis. Immunol. Rev. 2013, 252, 52-77. [CrossRef] [PubMed]

18. Knochelmann, H.M.; Dwyer, C.J.; Bailey, S.R.; Amaya, S.M.; Elston, D.M.; Mazza-McCrann, J.M.; Paulos, C.M. When worlds collide: Th17 and Treg cells in cancer and autoimmunity. Cell. Mol. Immunol. 2018. [CrossRef] [PubMed]

19. Collison, L.W.; Vignali, D.A. Interleukin-35: Odd one out or part of the family? Immunol. Rev. 2008, 226, 248-262. [CrossRef]

20. Ning-Wei, Z. Interleukin (IL)-35 is raising our expectations. Rev. Med. Chil. 2010, 138, 758-766. [CrossRef]

21. Egwuagu, C.E.; Yu, C.R.; Sun, L.; Wang, R. Interleukin 35: Critical regulator of immunity and lymphocyte-mediated diseases. Cytokine Growth Factor Rev. 2015, 26, 587-593. [CrossRef] [PubMed]

22. Collison, L.W.; Workman, C.J.; Kuo, T.T.; Boyd, K.; Wang, Y.; Vignali, K.M.; Cross, R.; Sehy, D.; Blumberg, R.S.; Vignali, D.A. The inhibitory cytokine IL-35 contributes to regulatory T-cell function. Nature 2007, 450, 566-569. [CrossRef] [PubMed]

23. Collison, L.W.; Chaturvedi, V.; Henderson, A.L.; Giacomin, P.R.; Guy, C.; Bankoti, J.; Finkelstein, D.; Forbes, K.; Workman, C.J.; Brown, S.A.; et al. IL-35-mediated induction of a potent regulatory T cell population. Nat. Immunol. 2010, 11, 1093-1101. [CrossRef]

24. Collison, L.W.; Delgoffe, G.M.; Guy, C.S.; Vignali, K.M.; Chaturvedi, V.; Fairweather, D.; Satoskar, A.R.; Garcia, K.C.; Hunter, C.A.; Drake, C.G.; et al. The composition and signaling of the IL-35 receptor are unconventional. Nat. Immunol. 2012, 13, 290-299. [CrossRef] [PubMed]

25. Niedbala, W.; Wei, X.Q.; Cai, B.; Hueber, A.J.; Leung, B.P.; McInnes, I.B.; Liew, F.Y. IL-35 is a novel cytokine with therapeutic effects against collagen-induced arthritis through the expansion of regulatory $\mathrm{T}$ cells and suppression of Th17 cells. Eur. J. Immunol. 2007, 37, 3021-3029. [CrossRef] [PubMed]

26. Whitehead, G.S.; Wilson, R.H.; Nakano, K.; Burch, L.H.; Nakano, H.; Cook, D.N. IL-35 production by inducible costimulator (ICOS)-positive regulatory $\mathrm{T}$ cells reverses established IL-17-dependent allergic airways disease. J. Allergy Clin. Immunol. 2012, 129, 207-215. [CrossRef] [PubMed]

27. Wirtz, S.; Billmeier, U.; McHedlidze, T.; Blumberg, R.S.; Neurath, M.F. Interleukin-35 mediates mucosal immune responses that protect against T-cell-dependent colitis. Gastroenterology 2011, 141, 1875-1886. [CrossRef] [PubMed]

28. Cai, Z.; Wong, C.K.; Dong, J.; Chu, M.; Jiao, D.; Kam, N.W.; Lam, C.W.; Tam, L.S. Remission of systemic lupus erythematosus disease activity with regulatory cytokine interleukin (IL)-35 in Murphy Roths Large (MRL)/lpr mice. Clin. Exp. Immunol. 2015, 181, 253-266. [CrossRef]

29. Hirschfield, G.M.; Liu, X.; Xu, C.; Lu, Y.; Xie, G.; Gu, X.; Walker, E.J.; Jing, K.; Juran, B.D.; Mason, A.L.; et al. Primary biliary cirrhosis associated with HLA, IL12A, and IL12RB2 variants. N. Engl. J. Med. 2009, 360, 2544-2555. [CrossRef]

30. Guo, T.; Yang, S.; Liu, N.; Wang, S.; Cui, B.; Ning, G. Association study of interleukin-12A gene polymorphisms with Graves' disease in two Chinese populations. Clin. Endocrinol. 2011, 74, 125-129. [CrossRef] 
31. Zhu, X.C.; Tan, L.; Jiang, T.; Tan, M.S.; Zhang, W.; Yu, J.T. Association of IL-12A and IL-12B polymorphisms with Alzheimer's disease susceptibility in a Han Chinese population. J. Neuroimmunol. 2014, 274, 180-184. [CrossRef] [PubMed]

32. Yamamoto-Furusho, J.K.; Posadas-Sanchez, R.; Alvarez-Leon, E.; Vargas-Alarcon, G. Protective role of Interleukin 27 (IL-27) gene polymorphisms in patients with ulcerative colitis. Immunol. Lett. 2016, 172, 79-83. [CrossRef] [PubMed]

33. Hochberg, M.C. Updating the American College of Rheumatology revised criteria for the classification of systemic lupus erythematosus. Arthritis Rheum 1997, 40, 1725. [CrossRef] [PubMed]

34. Barrett, J.C.; Fry, B.; Maller, J.; Daly, M.J. Haploview: Analysis and visualization of LD and haplotype maps. Bioinformatics 2005, 21, 263-265. [CrossRef] [PubMed]

35. Guo, L.; Zhou, X.; Guo, X.; Zhang, X.; Sun, Y. Association of interleukin-33 gene single nucleotide polymorphisms with ischemic stroke in north Chinese population. BMC Med. Genet. 2013, 14, 109. [CrossRef]

36. Li, Z.; Zhang, Z.; He, Z.; Tang, W.; Li, T.; Zeng, Z.; He, L.; Shi, Y. A partition-ligation-combination-subdivision EM algorithm for haplotype inference with multiallelic markers: Update of the SHEsis (http://analysis.bio- $x$. cn). Cell Res. 2009, 19, 519-523. [CrossRef]

37. Kleinewietfeld, M.; Hafler, D.A. The plasticity of human Treg and Th17 cells and its role in autoimmunity. Semin. Immunol. 2013, 25, 305-312. [CrossRef]

38. Su, L.C.; Liu, X.Y.; Huang, A.F.; Xu, W.D. Emerging role of IL-35 in inflammatory autoimmune diseases. Autoimmun. Rev. 2018. [CrossRef]

39. Cai, Z.; Wong, C.K.; Kam, N.W.; Dong, J.; Jiao, D.; Chu, M.; Lam, C.W.; Tam, L.S. Aberrant expression of regulatory cytokine IL-35 in patients with systemic lupus erythematosus. Lupus 2015, 24, 1257-1266. [CrossRef]

40. Nakano, S.; Morimoto, S.; Suzuki, S.; Tsushima, H.; Yamanaka, K.; Sekigawa, I.; Takasaki, Y. Immunoregulatory role of IL-35 in T cells of patients with rheumatoid arthritis. Rheumatology 2015, 54, 1498-1506. [CrossRef]

41. Kochetkova, I.; Golden, S.; Holderness, K.; Callis, G.; Pascual, D.W. IL-35 stimulation of CD39+ regulatory T cells confers protection against collagen II-induced arthritis via the production of IL-10. J. Immunol. 2010, 184, 7144-7153. [CrossRef]

42. Dantas, A.T.; Goncalves, S.M.; Pereira, M.C.; Goncalves, R.S.; Marques, C.D.; Rego, M.J.; Pitta Ida, R.; Duarte, A.L.; Pitta, M.G. Increased IL-35 serum levels in systemic sclerosis and association with pulmonary interstitial involvement. Clin. Rheumatol. 2015, 34, 1621-1625. [CrossRef] [PubMed]

43. Giovannetti, A.; Rosato, E.; Renzi, C.; Maselli, A.; Gambardella, L.; Giammarioli, A.M.; Palange, P.; Paoletti, P.; Pisarri, S.; Salsano, F.; et al. Analyses of T cell phenotype and function reveal an altered T cell homeostasis in systemic sclerosis. Correlations with disease severity and phenotypes. Clin. Immunol. 2010, 137, 122-133. [CrossRef] [PubMed]

44. Li, Y.; Wang, Y.; Liu, Y.; Zuo, X.; Lu, X. The possible role of the novel cytokines il-35 and il-37 in inflammatory bowel disease. Mediators Inflamm. 2014, 2014, 136329. [CrossRef] [PubMed]

45. Yang, Y.; Xuan, M.; Zhang, X.; Zhang, D.; Fu, R.; Zhou, F.; Ma, L.; Li, H.; Xue, F.; Zhang, L.; et al. Decreased IL-35 levels in patients with immune thrombocytopenia. Hum. Immunol. 2014, 75, 909-913. [CrossRef]

46. Wang, E.Y.; Yang, Q.; Liao, Z.G. Association of polymorphisms in interleukin (IL)-12A and -B genes with rheumatoid arthritis in a Chinese population. Clin. Exp. Immunol. 2015, 180, 83-89. [CrossRef]

47. Zhang, Y.; Duan, S.; Wei, X.; Zhao, Y.; Zhao, L.; Zhang, L. Association between polymorphisms in FOXP3 and EBI3 genes and the risk for development of allergic rhinitis in Chinese subjects. Hum. Immunol. 2012, 73, 939-945. [CrossRef] [PubMed]

48. Zheng, R.; Liu, H.; Song, P.; Feng, Y.; Qin, L.; Huang, X.; Chen, J.; Yang, H.; Liu, Z.; Cui, Z.; et al. Epstein-Barr virus-induced gene 3 (EBI3) polymorphisms and expression are associated with susceptibility to pulmonary tuberculosis. Tuberculosis 2015, 95, 497-504. [CrossRef]

49. Te, J.L.; Dozmorov, I.M.; Guthridge, J.M.; Nguyen, K.L.; Cavett, J.W.; Kelly, J.A.; Bruner, G.R.; Harley, J.B.; Ojwang, J.O. Identification of unique microRNA signature associated with lupus nephritis. PLoS One 2010, 5, e10344. [CrossRef]

50. Hahn, B.H.; McMahon, M.A.; Wilkinson, A.; Wallace, W.D.; Daikh, D.I.; Fitzgerald, J.D.; Karpouzas, G.A.; Merrill, J.T.; Wallace, D.J.; Yazdany, J.; et al. American College of Rheumatology guidelines for screening, treatment, and management of lupus nephritis. Arthritis Care Res. 2012, 64, 797-808. [CrossRef] [PubMed] 
51. He, D.; Liu, M.; Liu, B. Interleukin-35 as a New Biomarker of Renal Involvement in Lupus Nephritis Patients. Tohoku J. Exp. Med. 2018, 244, 263-270. [CrossRef] [PubMed]

52. Posadas-Sanchez, R.; Perez-Hernandez, N.; Angeles-Martinez, J.; Lopez-Bautista, F.; Villarreal-Molina, T.; Rodriguez-Perez, J.M.; Fragoso, J.M.; Posadas-Romero, C.; Vargas-Alarcon, G. Interleukin 35 Polymorphisms Are Associated with Decreased Risk of Premature Coronary Artery Disease, Metabolic Parameters, and IL-35 Levels: The Genetics of Atherosclerotic Disease (GEA) Study. Mediators Inflamm. 2017, 2017, 6012795. [CrossRef] [PubMed]

(C) 2019 by the authors. Licensee MDPI, Basel, Switzerland. This article is an open access article distributed under the terms and conditions of the Creative Commons Attribution (CC BY) license (http://creativecommons.org/licenses/by/4.0/). 